\title{
MATHEMATICAL MODELING OF OBJECTS FUNCTIONING AND TECHNICAL MEANS FOR AIRFIELD CONTROL ENSURING PROCESS
}

\author{
V.M. SAMOYLENKO ${ }^{1}$, O.V. GROMOV ${ }^{2}$, G.I. LITINSKY ${ }^{2}$, V.K. GROMOV ${ }^{2}$ \\ ${ }^{1}$ Moscow State Technical University of Civil Aviation, \\ Moscow, Russia, \\ ${ }^{2}$ LLC "Tupolev Service", Zhukovski, Russia
}

\begin{abstract}
In civil aviation primary focus is on the quality of fuel filled in the aircraft fuel tanks, as one of the components of flight safety ensuring. The introduction of digital technologies and trends in automation, digitalization of modern civil aviation aircraft provision are becoming the basic tool for civil aviation refueling complexes in terms of ensuring flight safety of civil aviation aircraft. This article considers the processes of airfield control that take place in the stationary operating conditions of refueling complexes of civil aviation airports as Markov processes and studies the approaches to their mathematical modeling. The authors claim that in the case of disruption, there is a transition from Markov to Poisson processes, which mathematical description requires different approaches. The practical application of these statements is obvious in the study of the states probabilities value as a function of time $t$. For practical purposes, the limiting probabilities of states at $\mathrm{t} \rightarrow \infty$ are of interest. This creates conditions for entering new variables, such as performance and others. Thus, Markov processes allow us to apply the mathematical apparatus of operations research, where the system of states is transformed into the queuing system. To maintain Markov processes, the authors suggest giving due consideration to the objects and technical means of airfield control functioning including: retrofitting of filling points and refueling facilities with closed sampling systems, operational measurement of aviation fuel quality indicators and registration of their results, automated monitoring of filter elements condition while refueling and its blocking in the case of stochastic differential pressure beyond the specified indicators. A special novelty is the view on the measuring process of the aircraft refueling operations as an integral part of airfield control, using block chain technologies as an advanced application of Markov chains.
\end{abstract}

Key words: fueling complex, mathematical modeling, airfield control, Markov processes, Poisson processes, Markov process maintenance, block chain technologies.

\section{INTRODUCTION}

Regular implementation of transportation volume in civil aviation of Russia requires carrying out aircraft fuel and lubricant service operations during the process of aircraft preparing for departure. The main task of refueling complexes in terms of strict compliance with the technological schedules of aircraft refueling during their preparation for departure is the organization of production processes and aviation fuel quality control. Aerodrome quality control of aviation fuel is the final technological operation, during which a final decision on the compliance of a certain fuel grade for refueling with a certain type of aircraft. At the present-day stage of development, facilities and technical means allowing us to execute high-quality and timely procedures for airfield control using the expanded format of aviation fuel study prior to aircraft refueling in the general chain of refueling complexes technological process, taking into consideration the priority of airfield fuel quality control. This also requires amendments into the current regulatory and technical documentation or developing new documentation that meets the requirements of the present-day existing technological processes.

\section{TESTS RESULTS AND THEIR DISCUSSION}

Mathematical modeling can be used as a tool for studying the operations of technological processes, including the processes of aircraft refueling. In their work, the authors rely on the fundamental concepts and methodological principles of mathematical modeling, using and applying the theory of 
Markov random processes [1-3], especially, concerning the theory of queuing of multi-element systems, as well as applying mathematical optimization methods (game theory, dynamic and linear programming, etc.).

The mathematical description of airfield control, in the modern extended sense, can be represented in the form of Markov chains [4,5]. A refueling operation can look like a sequence of random events in which a countable or finite number of operation outcomes can occur. In this respect, the probability of this event occurrence will depend on this event state, which was reached in the previous event. On that basis, the sequence of discrete random variables $\left\{X_{n}\right\} n \geq 0$ can be represented as a simple Markov chain with discrete time. Then the condition of this representation can be expressed as:

$$
\mathbf{P}\left(X_{n+1}=i_{n+1} \mid X_{n}=i_{n}, X_{n-1}=i_{n-1, \ldots,} X_{0}=i_{0}\right)=\mathbf{P}\left(X_{n+1}=i_{n+1} \mid X_{n}=i_{n}\right)
$$

The equation shows that the conditional distribution of the subsequent state of the Markov chain does not depend on the previous states, but only depends on the current state of the event under consideration. This is the distinguishing feature from higher-order Markov chains. Let us denote the domain of random variables $\left\{X_{n}\right\}$ as the state of the chain space, and the number can be designated as the pitch number.

Since the technological process of aviation fuel quality control (fig. 1) is a random process in which the value of the temporary parameter does not depend on the previous state, taking into account the specified value of the aircraft refueling process, so it has the characteristics of the Markov process. In Wentzel's interpretation [6], this can be represented as the "future" of the process depends on the "past" through the "present".
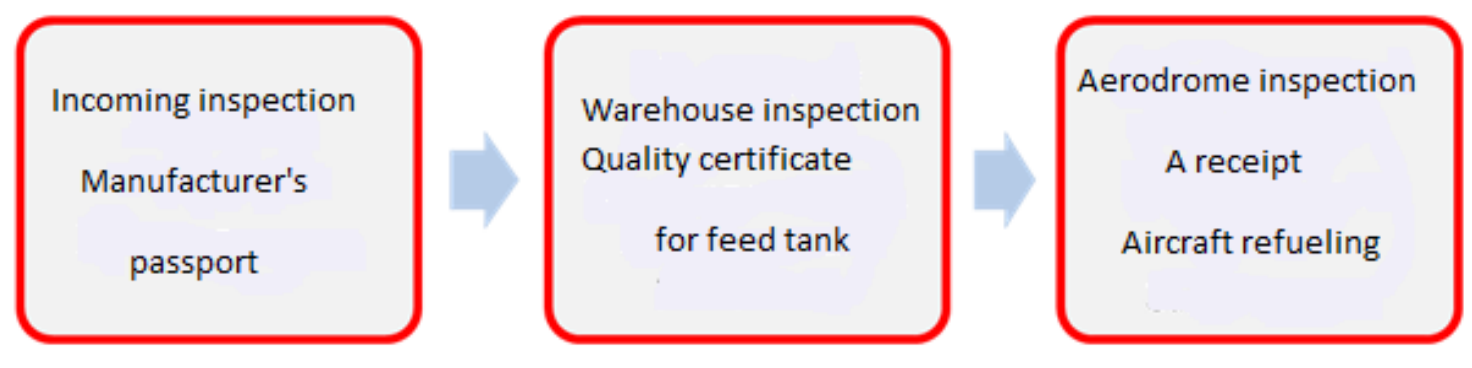

Fig. 1. The presentation of the Markov process control types and output documentation, which confirms the aviation fuel quality and phased fuel admission to refueling operations

In order to make mathematical description of airfield control, let us assume that its role in the Markov process is to confirm the readiness of the aircraft to be refueled by aircraft fuel suitable to use from the tank of a specific refueling vehicle and from the feed tank [4]. Since the system transition from the state of filling $S_{1}$ into a new sedimentation state $\boldsymbol{S}_{2}$, obtaining the control pass $\boldsymbol{S}_{3}$ and the aircraft refueling $\boldsymbol{S}_{4}$ is possible at any previously unknown, random moment of time $\boldsymbol{t}$, then, in order to simulate the process of aircraft refueling, which includes the technical means and objects of airfield control functioning, you can apply the definition of Markov homogeneous random processes with a discrete state and permanent time $[2,3]$, that is, the transition probability density of the $\lambda$ does not depend on time. Then the state graph will look as shown in Figure 2.

From the presented state graph of the aircraft refueling facilities, the probabilities of the $\boldsymbol{P}_{i g}(\boldsymbol{t})$ states can be determined as time variable, which corresponds to the Kolmogorov equations [1]. Using the system of Kolmogorov differential equations and the presented graph of the refueling facilities state, it is possible to obtain the probabilities of the aircraft refueling facilities states values as a timefunction. The probabilities of states at $t \rightarrow \infty$ are of interest for practical purposes. It is known that if the 
system number of states is finite and only several pitches can move you from one state into another, the limiting probabilities of the states exist at the condition of $\lambda=$ const, and are independent of the initial state of the system.

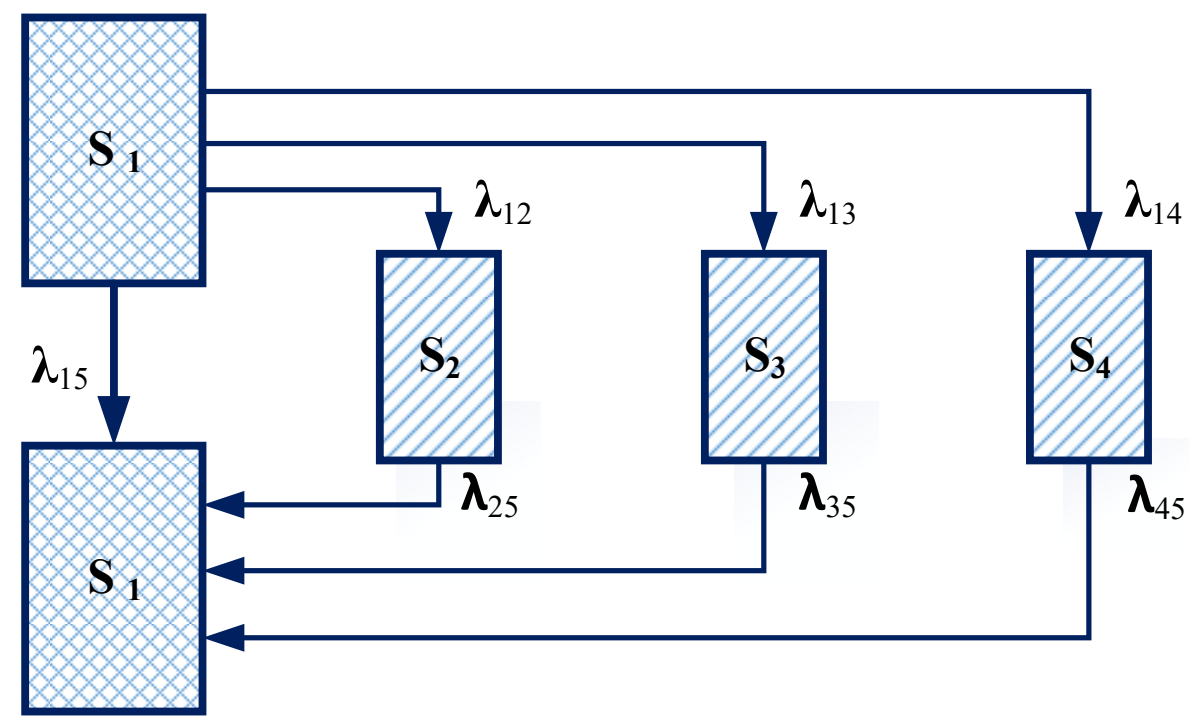

Fig. 2. Marked-up graph of the state of the aircraft refueling facilities

Consequently, at $\mathrm{t} \rightarrow \infty$, the maximum stationary mode is set in the system. This means that the system under consideration randomly changes its states. However, the probabilities of each one are no longer time-dependent. This means that each of the examined states can take place with certain constant probability, which is the mean non-dimensional time of system remaining in the given condition.

But, for practical application of these regulations, it is necessary to introduce new variables, such as the productivity of the object and others. Then, we apply the mathematical apparatus of operations research, and the system of states is transformed into the so-called mass or public service system (MSS) [4]. In this case, the airfield control along with the refueling and aircraft departure, acquire the property with a high probability of the waiting queues formation for aircraft maintenance during refueling.

Each mass service system (MSS) includes a certain number of service units, which are called service channels. It is known that each mass service system (MSS) under consideration depends on both the number of channels the system contains and their performance, as well as the origin of the orders flow. These dependencies affect the throughput capacity of the mass service system (MSS) and its ability to handle this flow of requests. Thus, the mass service systems (MSS) can be single and multichannel.

Airfield quality control of aviation fuel filled into the aircraft is the subject of the mass service theory (MST). This allows us to establish dependencies between the number of channels, the nature of the orders flow, their performance, operating rules and success, or, in other words, service efficiency [5].

However, at present, the working load on the mass service systems (MSS) is increasing, and at the same time they cope with the task of Markov processes, while they are in the condition of extreme stationary mode. If the process of aviation fuel and lubricants control, studied in the mass service systems (MSS) will be different from Markov process, then its efficiency characteristics can be estimated approximately as [6]. In this regard all further argumentation is carried out under the assumption that all consequence of events of the aviation fuel and lubricants aerodrome control, which transfer the mass service system (MSS) from one state into another, will be Poisson, that is, stochastic. And here it 
is necessary to examine the mathematical models of the mass service systems (MSS) operation in abnormal situations.

At the present-day stage of technology development, it is worth paying attention to the record keeping processes which are performed when the aircraft is being refueled, which enters the zone of responsibility of the aerodrome aviation fuel quality control service [7]. The development of the accounting is based on the measurement tools integration implemented into the fuel dispensers and on conducting transactions using block chains [8].

The Block chain technology [4, 9-11] for aerodrome control of aviation fuel and lubricants can be built in the form of a sequential and continuous chain of blocks that will contain information about the process and will be a derivative of Markov chains. A "linked list" will not only join the blocks by means of codes, addresses, and numbering, but also by the fact that each block contains its own hash sum as well as the hash sum of the previous block. If the information in one of the blocks is changed without authorization, it will require editing in all the subsequent blocks. In practice, in case of tamper protection, copies of block chains are stored on many different computers independently of each other. These actions make access to information extremely difficult, and particularly difficult to introduce changes into the blocks information.

To describe the block chain technology, let us refer to the description of a replicated distributed database implemented in the bitcoin system $[9,12]$. For this reason, the block chain technology is most often referred to transactions in various crypto currencies. However, the technology of block chains can be extended to any interconnected information blocks, including the Markov chain blocks of airfield control and the related technology of accounting transactions.

Today, the block chain technologies $[8,13]$ are applied in various fields of knowledge and technology, and, according to the authors, these technological methods can be used in performing the techniques of accounting transactions for aircraft refueling. To do this, it would be logical to implement the metering facilities of the airfield fuel tanker into the block chain technology to create the chain of information transmission received ranging from the measiring facilities of the airfield refueller to banking operations and receiving money for refueling an aircraft. This will eliminate cumbersome and inefficient accounting transactions and other related financial operations. In addition, the block chain can be used to identify the users of fuel supply services or create the cyber-security technologies to restrict access to its resources. But today, the block chain technologies are relevant primarily for executing banking operations and accounts and records to government organizations.

But, in order to implement the block chain technologies into practice of performing aircraft refueling operations, it is necessary to compile correctly the "chained list" [14, 15]. A "chained list", as a basic dynamic data structure, consists of units. Each of the units under consideration will contain both the data itself and one or two references or "bundles", to the previous and/or subsequent unit of the list.

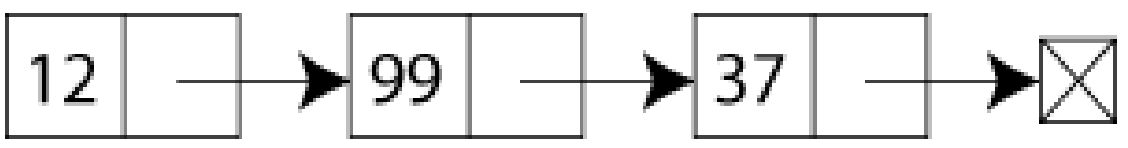

Fig. 3. Example of a linked list in the form of a single-linked list that contains 3 elements

The principal advantage of a linked list over a data array is its structural flexibility, where the order of the linked list elements may not coincide with the order of the data array elements in the computer memory, and the bypass order of the list is always set by its internal links. As it can be seen from the example (fig. 3), the linked list does not include the entire array of information, but only 3 elements bearing the necessary information [16].

It is important to notice that one of the block chain elements is the hash sum, which is considered as the result of data processing by the hash function $[14,16]$. In practice, the results of hash sum 
processing are used for the data integrity verification, their identification, and for the data replacement which is not safe to be stored in a computer database, such as passwords, logins, results of laboratory testing of jet fuel, and others. Hashing algorithms are used to verify the authenticity of files and their integrity.

Speaking about Markov processes, it is impossible to ignore the issue of equipping facilities and technical means of airfield control (fig. 4) with closed sampling systems and airfield control devices to ensure the aviation fuel transition to the aircraft tanks. First of all, the objects and technical means of airfield control include:

1. buildings, structures and equipment of filling stations;

2. aerodrome fuel tankers and refueling units of centralized aircraft refueling systems: mobile and stationary;

3. area and parking places for refueling facilities;

4. aircraft parking bays and traffic patterns of aircraft and refueling facilities;

5. processes and procedures for performing technological operations of refueling the aircraft, including the aircraft fuel system control (9) according to the IATA levels of responsibility.
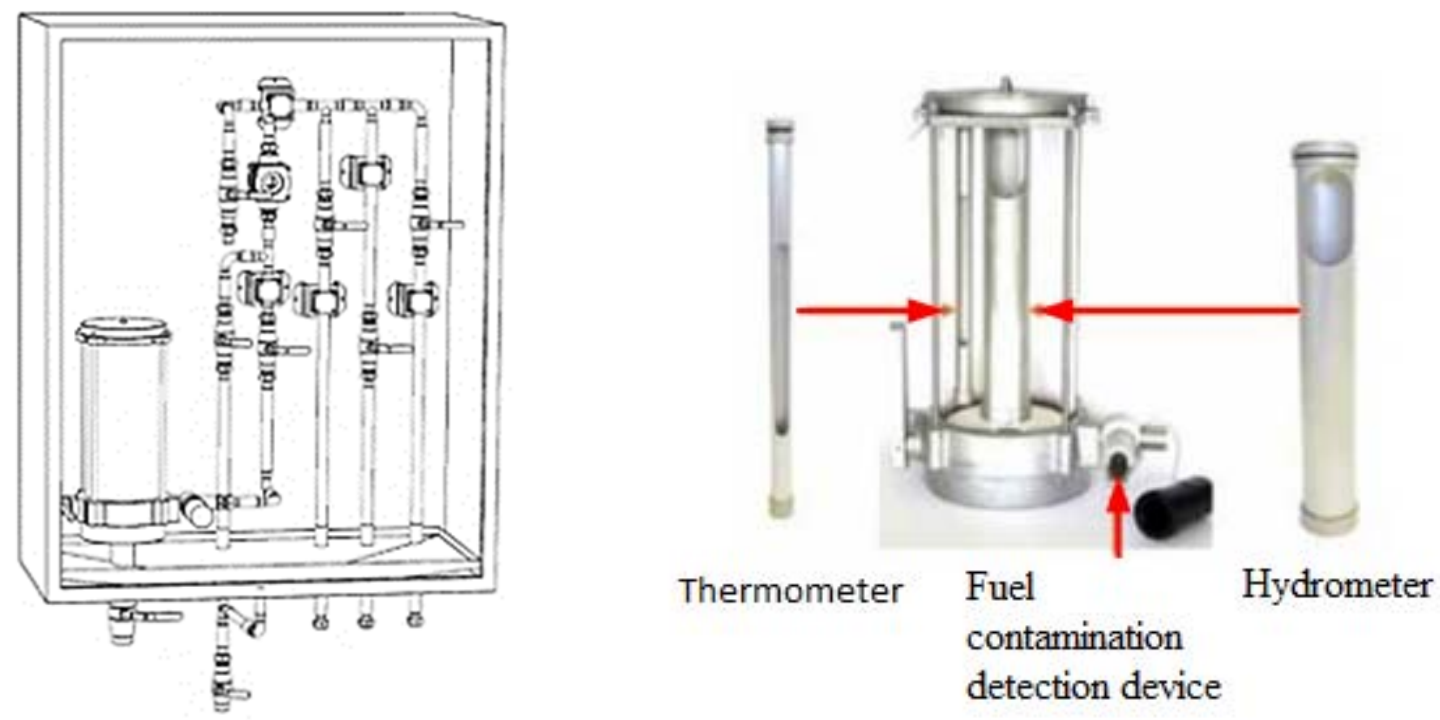

Fig. 4. An example of a closed sampling system embodiment

The objects of airfield quality control are micro filters and water separation filters of airfield fuel tankers, refueling units of central refueling station systems [17], mobile and stationary aircraft refueling facilities at the following points of the airport and airfield:

1. filling points and filtration points of central refueling station systems;

2. sedimentation and waiting areas;

3. aircraft ramps.

For filling and filtration points of central refueling station systems, in terms of technical equipment, the most important issues are the availability of a quality certificate of the feed tank and a quality control system fitting out with micro filters and water separation filters, as terminal technical infrastructure for fuel purification before using jet fuel. It is important to point out the requirement for application of closed sampling systems for instrument, visual and laboratory quality control. Today, it is an actual issue to develop the methodology for personnel dealing with closed sampling systems and conduct the visual and instrument control methods.

For the purposes of airfield control, it is important to replenish the refueling equipment with quality control devices (fig. 5), primarily of density and temperature [4, 9], which help to obtain effi- 
ciently quality indicators at technological sites and aircraft parking areas. It is recommended to use such devices as hydrometers, thermometers and fuel contamination detection devices in the set of refueling equipment. For their use, there are special pockets in the inner cover of the sampler for immersion of the instruments for measuring the indicators of airfield control in the controlled environment. Aerodrome control should use models of hydrometers and thermometers, which must be enclosed with the manufacturer's certificate of conformity, as well as ones approved by the aviation authorities and oil companies, compatible with the recommendations of the IATA-JIG [11, 18].

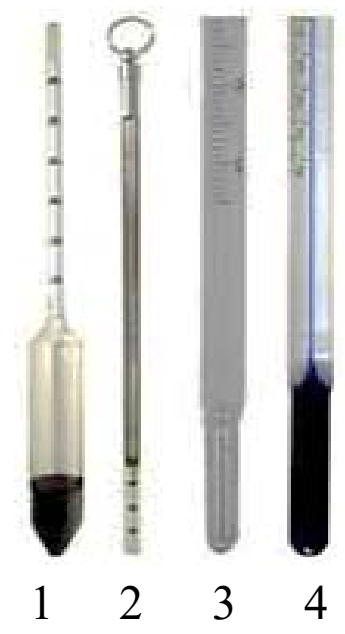

Fig. 5. Aerodrome control devices: thermometers $(1,2)$ and hydrometers $(3,4)$

In the lower part of the sampler there is a valve for entering the syringe of the fuel contamination detection device. The device is used for airfield control in order to determine the contamination of fuel with mechanical impurities and water. To determine the contamination of fuel, the fuel contamination detection device is used together with the fuel quality indicator.

Due to the high intensity of flights, today it is vital to refer on-line monitoring the contamination degree of micro-filters and water separator filters elements installed at the filling points and refueling facilities of the aircraft to the section of airfield control.

Periodic monitoring the differential pressure on the mentioned aviation fuel purification means is carried out within the limits of warehouse control [15], which is involved with the differential pressure indicators output beyond the limits which are limited while the airfield tankers are filled and, which is extremely dangerous, at the moment while the aircraft is being refueled. Since the value of the differential pressure is the function of filter elements state $[11,19]$, that is to say:

$$
P_{d} \cong f_{s}
$$

Where: $\boldsymbol{P}_{\boldsymbol{d}}-$ is the differential pressure of the filter element;

$\boldsymbol{f}_{\boldsymbol{s}}-$ is the function of the filter element condition.

In this case there is great probability of uncontrolled transition of purification system condition during the aircraft refueling on to aviation fuel quality dangerous indications while the system of aerodrome control won't be able to prevent it.

"Tupolev Service" LLC developed method of automated monitoring differential pressure current values for the water separator - filter consists of digitizing of the filter elements characteristics according to the manufacturer's technical documentation, by means of entering data into the software (hereinafter referred to as the software) compatible with the software of the aircraft refueling control inspector from its loading into the aircraft fuel tank controller (fig. 6) [15, 20]. 
A characteristic feature of the controller software is indication coming on in the event of the differential pressure parameters occurrence beyond the regulatory established limits for automatic aircraft refueling termination. Thus, the protection against non-normalized differential pressure is triggered. That is, the filling points filtration system and filling facilities should only function in the mode in which:

$$
\boldsymbol{P}_{\boldsymbol{d}}<\boldsymbol{P}_{d \max } \div>\boldsymbol{P}_{d \min }
$$

Where: $\boldsymbol{P}_{\boldsymbol{d} \text { max }}-$ is the maximum differential pressure;

$\boldsymbol{P}_{\boldsymbol{d} \text { min }}$ - is the minimal differential pressure.

Violation of the above-mentioned aviation fuel purification means operation mode automatically leads to an emergency stop of aircraft refueling.

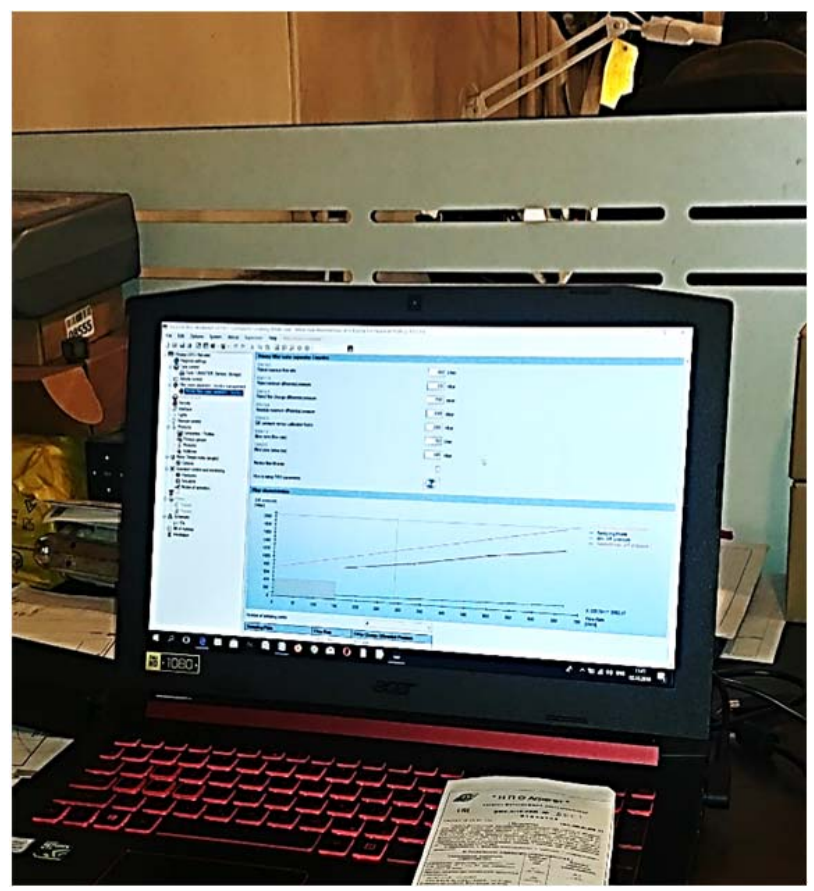

$a$

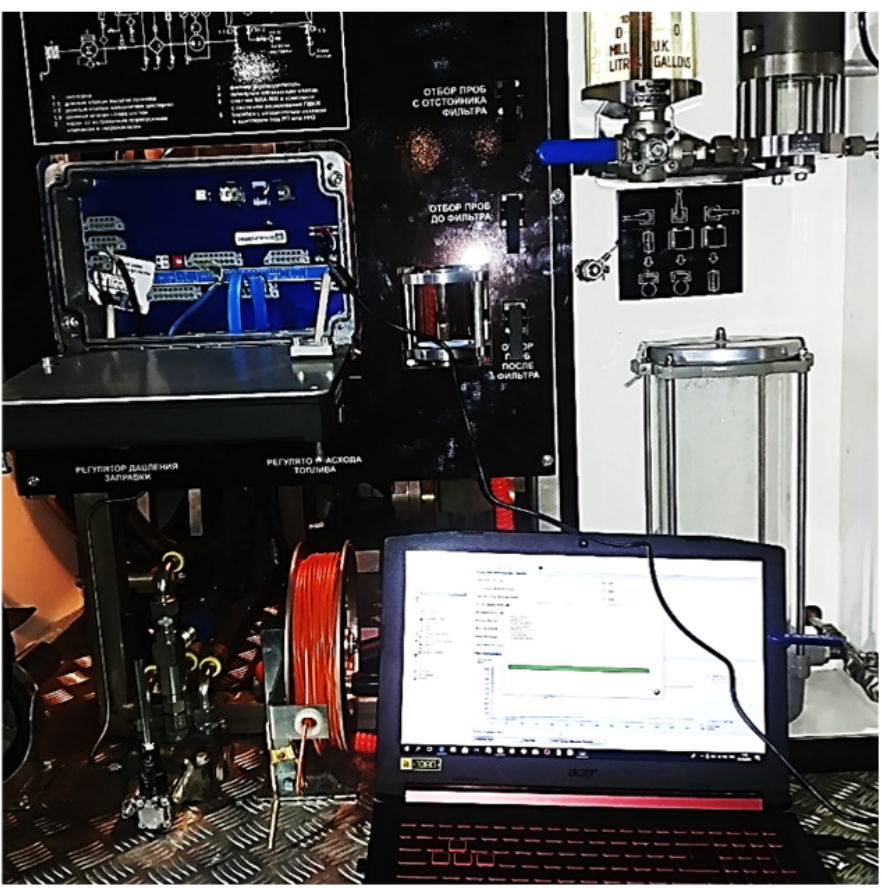

$b$

Fig. 6. Differential pressure passport data entry into the computer software (a) and their transmission to the on-board controller software (b)

The facilities and technical means of the aviation fuel objects purification system and the technical means of airfield control are as follows: the controller receives digital information from the flow parameter converter and in the On-line mode compares the differential pressure current data with the normalized ones, after which it issues a signal either to continue or terminate the aircraft refueling [4]. But, if the differential pressure indicator is beyond tolerance, the controller generates the aircraft refueling blocking signal.

\section{CONCLUSION}

1. Modern aerodrome control functions successfully in the conditions of Markov processes. In case of transition to Poisson processes mass service system reset is required.

2. In order to increase the aerodrome monitoring efficiency, modification of facilities and technical means which provide the aerodrome control functioning with closed sampling system and quality 
control devices with retraining of engineering staff and aircraft filling means operator-drivers is required.

3. The block chain technology implementation into the system of accounting transactions during the process of refueling operations will significantly increase the productivity of airport refueling complexes.

4. Aerodrome control should include the monitoring systems for checking the contamination of the micro-filter elements and water separator filters installed in aviation fuel purification systems at filling stations and airfield tankers.

5. The implementation of programs for the new methods of organizing airfield control and accounting operations introduction will require organizational and legal support from government structures.

\section{REFERENCES}

1. Kolmogorov, A.N. (1986). Teoriya veroyatnostey $i$ matematicheskaya statistika [Probability theory and mathematical statistics]. Moscow: Nauka, 534 p. (in Russian)

2. Gmurman, V.E. (2014). Teoriya veroyatnostey $i$ matematicheskaya statistika: uchebnik dlya vuzov [Probability theory and mathematical statistics: textbook for universities]. 12th ed. Moscow: Izdatelstvo Yurayt, 479 p. (in Russian)

3. Khamitov, G.P. and Vedernikova, T.I. (2006). Veroyatnosti i statistiki [Probabilities and statistics]. Irkutsk: BGUEP, 272 p. (in Russian)

4. Pirogov, Yu.N. (2006). Matematicheskoye modelirovaniye protsessov funktsionirovaniya obyektov tekhnicheskikh sredstv obespecheniya goryuchim [Mathematical modeling of the refueling technical facilities functioning processes]. Moscow: Neografiya, 228 p. (in Russian)

5. Kleinrock, L. (1975). Queueing Systems, Volume 1: Theory. Wiley-Interscience, 448 p.

6. Wentzel, E.S. (2004). Issledovaniye operatsiy: zadachi, printsipy, metodologiya: uchebnoye posobiye dlya vuzov [Operations research: tasks, principles, methodology: Textbook for university students]. 3rd ed., ster. Moscow: Drofa, 208 p. (in Russian)

7. Leshchiner, L.B., Ulyanov, I.E. and Tveretskiy, V.A. (1975). Proyektirovaniye toplivnykh sistem samoletov [Design of aircraft fuel systems]. 1st ed., in Skubachevsky T.S. (Ed.). Moscow: Mashinostroyeniye, 334 p. (in Russian)

8. Swan, M. (2015). Blockchain: blueprint for a new economy. 1st ed. O'Reilly Media, 152 p.

9. Pegat, A. (2001). Fuzzy modeling and control. Physica-Verlag Heidelberg, 728 p. DOI: 10.1007/978-3-7908-1824-6

10. Gromov, V.K. (2011). Kontseptsiya modernizatsii. Protsessnyy podkhod $k$ organizatsii toplivozapravochnykh kompleksov aeroportov [The concept of modernization. Process approach to the organization of airports refueling complexes]. Assotsiatsiya OATO VS GA, no. 6, pp. 36-41. (in Russian)

11. Seregin, E.P. (2018). Razvitiye himmotologii [Development of chemmotology]. Moscow: Pervyy tom, 880 p. (in Russian)

12. Mougayar, M. and Buterin, V. (2016). Blockchain for business. 1st ed. Wiley, $196 \mathrm{p}$.

13. Genkin, A. and Mikheev, A. (2018). Blokcheyn. Kak eto rabotayet $i$ chto zhdet nas zavtra [Blockchain. How it works and what awaits us tomorrow]. Moscow: Alpina Publisher, 592 p. (in Russian) (in French)

14. Leloup, L. (2017). Blockchain: La révolution de la confiance. EYROLLES, 226 p.

15. Kraev, A.K. and others. (2005). Agregaty i komplektuyushcheye oborudovaniye sredstv perekachki, zapravki i transportirovka raketnogo topliva i goryuchego: uchebnoye posobiye [Aggregates and component equipment for pumping, refueling and transportation of rocket fuel and fuel: Tutorial]. 2nd ed., pererab. i dopol. Ulyanovsk: UVVATU, 202 p. (in Russian) 
16. Tapscott, A. and Tapscott, D. (2016). Blockchain revolution: how the technology behind bitcoin is changing money, business, and the world. Portfolio, $365 \mathrm{p}$.

17. Kovalenko, V.G. and Sereda, V.V. (2005). Avtomobilnyye transportno-zapravochnyye sredstva dlya neftyanykh i gazovykh topliv. Spravochnik-albom. Nauchno-tekhnicheskoye izdaniye [Automobile transport and filling facilities for oil and gas fuels. Directory-album. Scientific and technical edition]. Moscow: OOO "Vladmar", 224 p. (in Russian)

18. Kauk, V.V., Dunayev, S.V., Shatalov, K.V., Alatortsev, Ye.I. and others. (2008). Analiz kachestva goryuchego [Analysis of fuel quality], 696 p. (in Russian)

19. Syroedov, N.Ye. and Rozhkov, A.F. (1992). Zarubezhnyye mobilnyye toplivozapravochnyye sistemy i sistemy tsentralizovannoy zapravki toplivom letatelnykh apparatov. Obzor [Foreign mobile fuel filling systems and systems of centralized refueling of aircraft. Review]. Moscow: 25 GosNII MO RF, 116 p. (in Russian)

20. Dronov, D.V. (2005). Avtonomnyye sredstva zapravki letatelnykh apparatov: uchebnoye posobiye [Autonomous means of refueling aircraft: Textbook]. 2nd ed., pererab. i dopol. Ulyanovsk: UVVATU, 234 p. (in Russian)

\title{
INFORMATION ABOUT THE AUTHORS
}

Vasily M. Samoilenko, Doctor of Technical Sciences, Professor, the Head of the Aviation Fuel Supply and Aircraft Repair Chair, Moscow State Technical University of Civil Aviation, v.samoilenko@mstuca.aero.

Oleg V. Gromov, Candidate of Sciences in Economics, Consultant to the General Director, LLC "Tupolev Service", o.gromov@sorge.pro.

Grigory I. Litinsky, General Director, LLC "Tupolev Service", jobgregor2@gmail.com.

Vladimir K. Gromov, Consultant to the General Director, LLC "Tupolev Service", v.k.gromov@gmail.com.

\section{МАТЕМАТИЧЕСКОЕ МОДЕЛИРОВАНИЕ ПРОЦЕССА ФУНКЦИОНИРОВАНИЯ ОБЪЕКТОВ И ТЕХНИЧЕСКИХ СРЕДСТВ ОБЕСПЕЧЕНИЯ АЭРОДРОМНОГО КОНТРОЛЯ}

\author{
В.М. Самойленко ${ }^{1}$, О.В. Громов ${ }^{2}$, Г.И. Литинский ${ }^{2}$, В.К. Громов ${ }^{2}$ \\ ${ }^{1}$ Московский государственный технический университет гражданской авиаичи, \\ 2. Москва, Россия \\ ${ }^{2}$ ООО «Туполев Сервис», г. Жуковский, Россия
}

\begin{abstract}
В гражданской авиации большое внимание уделяется качеству топлива, заправляемого в топливные баки воздушного судна, как одной из составляющих обеспечения безопасности полетов. Внедрение цифровых технологий и тенденций автоматизации, цифровизации современного авиатопливообеспечения воздушных судов гражданской авиации (ВС ГА) становится базовым инструментом топливозаправочных комплексов ГА в обеспечении безопасности полетов ВС ГА. В данной статье процессы аэродромного контроля, протекающие в стационарных условиях работы топливозаправочных комплексов аэропортов гражданской авиации, рассматриваются как Марковские, и изучены подходы к их математическому моделированию. Авторы утверждают, что в случае сбойных ситуаций происходит переход от Марковских к Пуассоновским процессам, математическое описание которых требует иных подходов. Практическое применение этих положений видится в рассмотрении значения вероятностей состояний как функции времени $\boldsymbol{t}$. Для практических целей интерес представляют предельные вероятности состояний при $\boldsymbol{t} \rightarrow \infty$. Это создает условия для ввода новых переменных, таких как производительность и другие. Таким образом, Марковские процессы позволяют применять математический аппарат исследования операций, где система состояний преобразуется в систему массового обслуживания (CMO). Для поддержания Марковских процессов авторы предлагают уделить особое внимание функционированию объектов и технических средств аэродромного контроля, среди которых дооснащение пунктов налива и средств заправки закрытыми системами отбора проб, оперативное измерение показателей качества авиатоплива
\end{abstract}


и оформление их результатов, автоматизация мониторинга состояния фильтрующих элементов в процессе заправки и его блокировка в случае стохастических выходов перепада давления за нормируемые показатели. Особую новизну представляет видение процесса ведения учетных операций заправки воздушных судов как неотъемлемой части аэродромного контроля с применением технологий блокчейн, продвинутого приложения Марковских цепей.

Ключевые слова: топливозаправочный комплекс, математическое моделирование, аэродромный контроль, Марковские процессы, Пуассоновские процессы, поддержание Марковского процесса, технологии блокчейн.

\section{СПИСОК ЛИТЕРАТУРЫ}

1. Колмогоров А.Н. Теория вероятностей и математическая статистика. М.: Наука, 1986. $534 \mathrm{c}$.

2. Гмурман В.Е. Теория вероятностей и математическая статистика: учебник для вузов. 12-е изд. М.: Юрайт, 2014. 479 с.

3. Хамитов Г.П., Ведерникова Т.И. Вероятности и статистики. Иркутск: БГУЭП, 2006. $272 \mathrm{c}$.

4. Пирогов Ю.Н. Математическое моделирование процессов функционирования объектов технических средств обеспечения горючим. М.: Неография, 2006. 228 с.

5. Клейнрок Л. Теория массового обслуживания / Пер. с англ. И.И. Грушко, под ред. В.И. Неймана. М.: Машиностроение, 1979. 432 с.

6. Вентцель Е.С. Исследование операций: задачи, принципы, методология: учеб. пособие для вузов. 3-е изд., стер. М.: Дрофа, 2004. 208 с.

7. Лещинер Л.Б., Ульянов И.Е., Тверецкий В.А. Проектирование топливных систем самолетов / Под ред. Т.С. Скубачевского. 1-е изд. М.: Машиностроение, 1975. 334 с.

8. Свон М. Блокчейн. Схема новой экономики. М.: Олимп-бизнес, 2017. 240 с.

9. Пегат А. Нечеткое моделирование и управление: пер. с англ. 2-е изд. М.: Бином. Лаборатория знаний, 2013. 798 с.

10. Громов В.К. Концепция модернизации. Процессный подход к организации топливозаправочных комплексов аэропортов // Ассоциация ОАТО ВС ГА. Информационный сборник. 2011. № 6. C. 36-41.

11. Серегин Е.П. Развитие химмотологии. М.: Первый том, 2018. 880 с.

12. Могайар У., Бутерин В. Блокчейн для бизнеса. М.: Бомбора, 2017. 224 с.

13. Генкин А., Михеев А. Блокчейн. Как это работает и что ждет нас завтра. М.: Альпина Паблишер, 2018. 592 с.

14. Лелу Л. Блокчейн от А до Я. Все о технологии десятилетия. М.: Бомбора, 2018. 256 с.

15. Краев А.К. Агрегаты и комплектующее оборудование средств перекачки, заправки и транспортировки ракетного топлива и горючего: учеб. пособие / А.К. Краев и др. 2-е изд., перераб. и доп. Ульяновск: УВВАТУ, 2005. 202 с.

16. Тапскотт А., Тапскотт Д. Технология блокчейн - то, что движет финансовой революцией сегодня. М.: Бомбора, 2017. 448 с.

17. Коваленко В.Г., Середа В.В. Автомобильные транспортно-заправочные средства для нефтяных и газовых топлив. Справочник-альбом. Научно-техническое издание. М.: ООО «Владмар», 2005. 224 с.

18. Каук В.В. Анализ качества горючего / В.В. Каук, С.В. Дунаев, К.В. Шаталов, Е.И. Алаторцев и др. М.: ООО «Ульяновский Дом печати», 2008. 696 с.

19. Сыроедов Н.Е., Рожков А.Ф. Зарубежные мобильные топливозаправочные системы и системы централизованной заправки топливом летательных аппаратов. Обзор. М.: 25 ГосНИИ МО РФ, 1992. $116 \mathrm{c}$.

20.Дронов Д.В. Автономные средства заправки летательных аппаратов: учеб. пособие / Д.В. Дронов и др. 2-е изд., перераб. и доп. Ульяновск: УВВАТУ, 2005. 234 с. 


\section{СВЕДЕНИЯ ОБ АВТОРАХ}

Самойленко Василий Михайлович, доктор технических наук, заведующий кафедрой авиатопливообеспечения и ремонта летательных аппаратов МГТУ ГА, v.samoilenko@mstuca.aero.

Громов Олег Владимирович, кандидат экономических наук, советник генерального директора ООО «Туполев Сервис», o.gromov@sorge.pro.

Литинский Григорий Иванович, генеральный директор ООО «Туполев Сервис», jobgregor2@gmail.com.

Громов Владимир Константинович, советник генерального директора ООО «Туполев Сервис»,v.k.gromov@gmail.com.

Поступила в редакцию

Принята в печать
18.12 .2020

25.03.2021
Received

18.12 .2020

Accepted for publication
25.03.2021 